\title{
Working
}

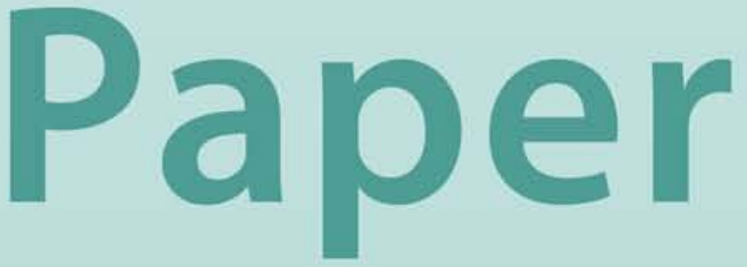


A Fair Exchange? Theory and Practice of Calculating Equilibrium Exchange Rates

Tamim Bayoumi, Hamid Faruqee, and Jaewoo Lee 


\title{
IMF Working Paper
}

Western Hemisphere and Research Departments

\section{A Fair Exchange? Theory and Practice of Calculating Equilibrium Exchange Rates}

\author{
Prepared by Tamim Bayoumi, Hamid Faruqee, and Jaewoo Lee ${ }^{1}$ \\ Authorized for distribution by Tamim Bayoumi
}

December 2005

\begin{abstract}

\section{This Working Paper should not be reported as representing the views of the IMF.} The views expressed in this Working Paper are those of the author(s) and do not necessarily represent those of the IMF or IMF policy. Working Papers describe research in progress by the author(s) and are published to elicit comments and to further debate.
\end{abstract}

We develop a theory-based model of equilibrium exchange rates incorporating factors that have been found to matter empirically. The model provides insights into how variables should be measured and what are appropriate cross-country restrictions. We estimate this model using a panel of 12 industrial countries. The model fits the data relatively well, implying relatively fast adjustment to equilibrium and outperforming a random walk at longer horizons. Furthermore, we find that the rate of adjustment depends on the distance from equilibrium, suggesting that part of the explanation for slow adjustment is inaccurate measures of equilibrium.

JEL Classification Numbers: F31, F41

Keywords: Exchange rates, imperfect substitutability, nonlinear convergence

Author(s) E-Mail Address: tbayoumi@imf.org; hfaruqee@imf.org; jlee3@imf.org

\footnotetext{
${ }^{1}$ We appreciate the assistance by Sarma Jayanthi, and comments and suggestions by many colleagues in and outside the IMF.
} 


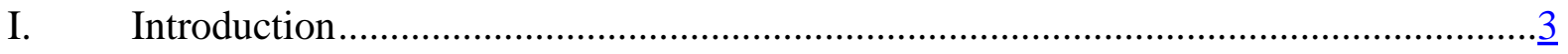

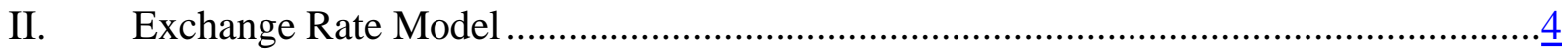

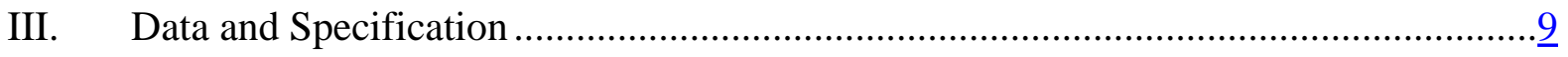

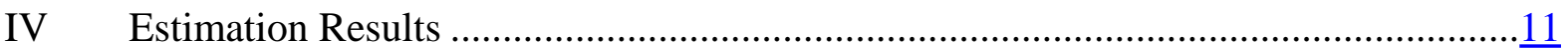

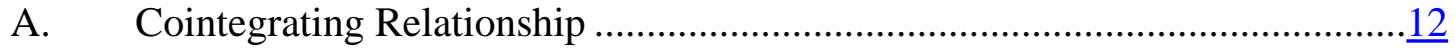

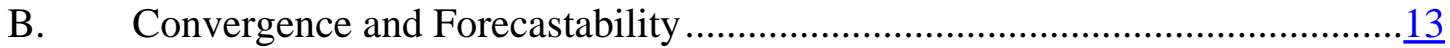

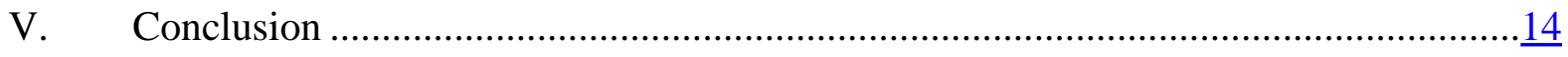

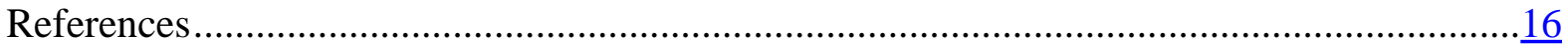

Appendices

I. Derivation of Relative Price of Commodities...................................................18

II Derivation of Log-Linearized Exchange Rate Equation......................................... 19

III Data Sources .....................................................................................

\section{Tables}

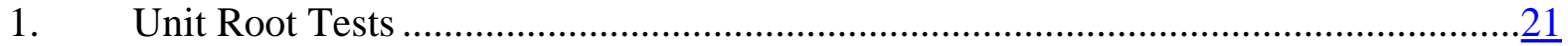

2. Panel Estimates of Long-Run Coefficients....................................................22

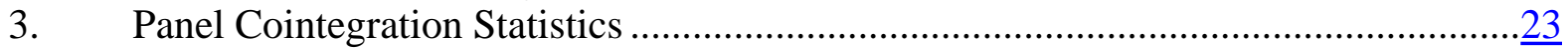

4. Panel Estimates of Error-Correction Model .......................................................... 24

5. More Panel Estimates of Error-Correction Model.................................................25

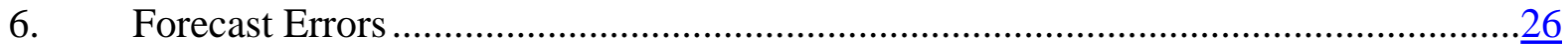




\section{INTRODUCTION}

How predictable are exchange rates? As regards the short term (measured in days or weeks), the general view is that the nominal rate is completely unpredictable, so that the best predictor of the exchange rate tomorrow is its current value. ${ }^{2}$ Taken literally, this would imply that such unpredictability extends out to all periods, with the future path being defined solely by relevant interest rate differentials in financial markets.

An increasingly dominant view, however, is that over the medium term (business cycle frequencies of say three to seven years) real exchange rates tend to move towards an underlying “equilibrium” value defined by real factors, usually defined by some version of purchasing power parity (PPP). Indeed, the slow rate of return to PPP was listed as one of the "six puzzles" of international finance. ${ }^{3}$ This view, however, needs to be reconciled with empirical evidence that exchange rates depend upon a country's stage of development (Balassa-Samuelson effects), trends in net foreign asset positions, and on commodity prices. ${ }^{4}$ That said, attempts to integrate the underlying factors that determine equilibrium real exchange rates into a single model have gained little acceptance, in large part because of the perceived lack of theoretical underpinnings. ${ }^{5}$

Changes in the substitutability of domestic and foreign traded goods are an appealing way of reconciling these various strands of the exchange rate literature. In the short run, trade is essentially predetermined, and the value of the exchange rate is dominated by unpredictable shocks emanating from highly efficient financial markets. Over the medium term, however, it becomes possible to substitute traded goods and hence the exchange rate is increasingly dominated by forces that determine their relative prices, such as net international investment positions and commodity prices. Over longer periods, as the structure of production also changes, the exchange rate is increasingly converges to PPP.

This paper focuses on the determination of exchange rates across business cycle frequencies and hence the middle segment of this time scale. An equilibrium exchange rate model built on strong microeconomic underpinnings is derived and estimated assuming that domestic and foreign manufactured traded goods are imperfect substitutes. As a result, their relative price (the real exchange rate in this paper) depends upon relative supply of such goods and other determinants of the current account, such as interest payments on net foreign assets and terms

\footnotetext{
2 The seminal paper being Meese and Rogoff (1983).

${ }^{3}$ Obstfeld and Rogoff (2000).

${ }^{4}$ On the stage of development, see Balassa (1964), Samuelson (1964), and the review of recent contributions in Lee and Tang (2003). On net foreign assets, see Faruqee (1995), Gagnon (1996), and Lane and Milesi-Ferretti (2001 and 2004). On terms of trade, see Cashin, Céspedes, and Sahay (2002) and Chen and Rogoff (2003).

5 See Williamson (1994), Clark and MacDonald (1998).
} 
of trade shocks from commodity prices. In the estimation, Balassa-Samuelson effects are incorporated by focusing solely on relative prices of manufactures.

The rest of the paper is organized as follows. The theoretical model is presented in Section II, data and specification in Section III, and results in Section IV. Section V concludes.

\section{EXCHANGE RATE MODEL}

We derive a static, two-country flexible-price model in which the real exchange rate depends upon factors such as commodity prices and the evolution of external debt payments while being flexible enough to incorporate difference between the home country and the rest of the world with regard to relative sizes of economies, the role of commodities in trade, and the degree of home bias in consumption. The resulting estimating equation contains further insights, such as the importance of the relative supply of home and foreign traded goods, as well as the composition of exports and imports in determining the exchange rate.

The world comprises two countries, home and a (larger) foreign one, the latter's variables denoted by a star. Each country produces three types of goods: a nontraded consumption good $(\mathrm{N})$, a traded manufactured good (M) which is consumed, and a traded commodity (C) used in the production of the other two goods. Home and foreign goods are differentiated, so there are six goods, $\mathrm{N}, \mathrm{N}^{*}, \mathrm{M}, \mathrm{M}^{*}, \mathrm{C}$, and $\mathrm{C}^{*}$. There are two factors of production with fixed endowments: labor, used to produce the traded and nontraded goods, and land, used to produce commodities. The exclusion of capital from the model avoids the complications analyzing the accumulation process. Prices are fully flexible and markets are assumed competitive.

\section{Production}

The production technology determines the relative prices between nontraded and manufactured goods. Both goods are produced using constant-returns to scale Leontief technologies between labor and each of the two commodities and differ only with regard to productivity. Formally:

$$
\begin{aligned}
& Y_{M}=T_{M} \operatorname{Min}\left(L_{M}, \frac{I_{M}}{\varphi_{C}}, \frac{I_{M^{*}}}{\varphi_{C^{*}}}\right) \\
& Y_{N}=T_{N} \operatorname{Min}\left(L_{N}, \frac{I_{N}}{\varphi_{C}}, \frac{I_{N}^{*}}{\varphi_{C^{*}}}\right) \\
& Y_{M^{*}}=T_{M^{*}} \operatorname{Min}\left(L_{M^{*}}, \frac{I_{M^{*}}}{\varphi_{C}}, \frac{I_{M^{*}}^{*}}{\varphi_{C^{*}}}\right) \\
& Y_{N^{*}}=T_{N^{*}} \operatorname{Min}\left(L_{N^{*}}, \frac{I_{N^{*}}}{\varphi_{C}}, \frac{I_{N^{*}}^{*}}{\varphi_{C^{*}}}\right)
\end{aligned}
$$


where $Y_{i}\left(Y_{i_{*}}\right)$ is home (foreign) output in sector $\mathrm{i}, \mathrm{T}_{\mathrm{i}}\left(\mathrm{T}_{\mathrm{i}^{*}}\right)$ are productivity shocks, $I_{i}\left(I_{i^{*}}\right)$ are inputs of commodities by sector $I$, and $\alpha, \varphi_{\mathrm{C}}$, and $\varphi_{\mathrm{C}^{*}}$ are positive parameters between zero and one.

The home country is endowed with one unit of labor, and the foreign country with s units (assumed greater than one). The resource constraints are thus:

$$
\begin{aligned}
& L_{N}+L_{T}=1 \\
& L^{*}{ }_{N}+L^{*}{ }_{T}=S
\end{aligned}
$$

The foreign price of manufactures, $P_{M^{*}}$, is the numerator.

Assuming the Leontief constraints bind, we have:

$$
\begin{aligned}
& Y_{M}=T_{M} L_{M} \\
& Y_{N}=T_{N} L_{N}=T_{N}\left(1-L_{M}\right)
\end{aligned}
$$

It follows from the cost side of the model that the price of nontraded goods and manufactures in the home country is:

$$
\begin{aligned}
& T_{M} P_{M}=W+\varphi_{c} P_{c}+\varphi_{c^{*}} P_{c^{*}} \\
& T_{N} P_{N}=W+\varphi_{c} P_{c}+\varphi_{c^{*}} P_{c^{*}}
\end{aligned}
$$

As a result:

$$
\frac{P_{N}}{p_{M}}=\frac{T_{M}}{T_{N}}
$$

with a similar expression for the foreign country. The relative price of nontraded goods to manufactured goods in each country is thus driven by relative productivities in the two sectors - the Balassa-Samuelson effect.

Commodity $C\left(C^{*}\right)$ is produced only in the home (foreign) country using a linear production function by a separate nontradable factor, land denoted $A\left(A^{*}\right)$, plus a productivity shock, $T_{C}$ $\left(\mathrm{T}_{\mathrm{C}^{*}}\right)$ :

$$
Y_{C}=T_{C} A
$$


The intensity of land use depends on the relative rental price of land (which equals the price of commodities) to wages. ${ }^{6}$ Using the derivation in Appendix I it can be shown that:

$$
\begin{aligned}
& P_{c}=T_{M} P_{M}\left(\frac{\varphi_{c}(1+s)}{T_{c} \bar{A}}\right)^{1 / \lambda} \\
& Y_{c}=\varphi_{c}(1+s) \\
& C_{c}=I_{M}+I_{N}=\varphi_{c} \text { and } X_{c}=I_{M^{*}}+I_{N^{*}}=\varphi_{c} s
\end{aligned}
$$

with equivalent foreign relationships, where $\lambda$ is assumed to be less than one to reflect the stylized fact that shocks to output of commodities produce larger-than-proportional changes in prices. Prices of commodities depend on the global labor force $(1+s)$, commodity intensity of production $\left(\varphi_{c}\right)$, productivity of land $\left(\mathrm{T}_{\mathrm{c}}\right)$, and the relative price and productivity of manufactures. Output of the home commodity $\left(\mathrm{Y}_{\mathrm{C}}\right)$, home consumption $\left(\mathrm{C}_{\mathrm{C}}\right)$, and exports of the home commodity $\left(\mathrm{X}_{\mathrm{C}}\right)$ depend only upon the world labor supply and shocks to the productivity of land.

\section{Consumption}

The representative agent's utility function has greater substitutability between home and foreign manufactured goods than across manufactured and nontraded goods. This is captured by having Cobb-Douglas preferences between the nontraded and manufactured goods, and CES preferences across the home and foreign manufactured goods with an elasticity of substitution of $\varepsilon$, which is greater than unity:

$$
U=C_{N}{ }^{(1-\beta)}\left((1-\gamma)^{\frac{1}{\varepsilon}} C_{M}^{\frac{\varepsilon-1}{\varepsilon}}+\gamma^{\frac{1}{\varepsilon}} X_{M}^{*^{\frac{\varepsilon-1}{\varepsilon}}}\right)^{\frac{\beta \varepsilon}{\varepsilon-1}}
$$

where $C_{N}, C_{M}$, and $X_{M}^{*}$ are consumption of the home nontraded good, home manufactures, and foreign manufactures (which are exported from the foreign country, hence the $X^{*}$ ), respectively, and $\beta, \gamma$, and $\varepsilon$ are positive parameters. The utility function for the foreign consumer is similar, with $\varepsilon$ and $\beta$ being assumed the same, while the relationship between $\gamma$ and $\gamma^{*}$ depends upon the relative sizes of the two economies, the structure of production, and the composition of trade. It helps at this stage to write the nonmanufacturing current account balance, comprising the balance on commodity trade and transfers ( $T R$, priced in foreign manufactures), as:

\footnotetext{
6 This can be justified by assuming that the production of commodities also uses infinitesimal inputs of labor.
} 


$$
Z=P_{c} X_{c}-P_{c} X_{c^{*}}+T R=X_{M^{*}}-P_{M} X_{M}
$$

To solve for the relative prices of the two manufactured goods, note that as for nontraded goods, production equals consumption:

$$
\begin{aligned}
& P_{M} Y_{M}+Z=P_{M} C_{M}+X_{M^{*}} \\
& Y_{M^{*}}-Z=C_{M^{*}}+P_{M} X_{M}
\end{aligned}
$$

The CES utility function implies that:

$$
\begin{aligned}
C_{M} & =\frac{1-\gamma}{\gamma} X_{M^{*}}^{*} P_{M}^{-\varepsilon} \\
C_{M^{*}} & =\frac{1-\gamma^{*}}{\gamma^{*}} X_{M} P_{M}^{\varepsilon}
\end{aligned}
$$

Combining with the budget constraints gives:

$$
\begin{aligned}
& X_{M^{*}}=\frac{\gamma\left(P_{M} Y_{M}+Z\right)}{\gamma+(1-\gamma) P_{M}^{-(\varepsilon-1)}} \\
& P_{M} X_{M}=\frac{\gamma^{*}\left(Y_{M^{*}}-Z\right)}{\gamma^{*}+\left(1-\gamma^{*}\right) P_{M}^{(\varepsilon-1)}}
\end{aligned}
$$

Equation (12) can be combined with the budget constraint on the trade balance $P_{M} X_{M}+Z=X_{M^{*}}$ to produce the following expression for the relative prices of the two manufactured goods:

$$
\frac{\gamma\left(P_{M} Y_{M}+Z\right)}{y+(1-\gamma) P_{M}^{-(\varepsilon-1)}}=\frac{\gamma^{*}\left(Y_{M^{*}}-Z\right)}{\gamma^{*}+\left(1-\gamma^{*}\right) P_{M}^{\varepsilon-1}}+Z
$$

Rewriting gives: 


$$
\begin{aligned}
\frac{P_{M}\left(\gamma^{*}+\left(1-\gamma^{*}\right) P_{M}^{\varepsilon-1}\right)}{y+(1-\gamma) P_{M}^{-(\varepsilon-1)}} & =\frac{\gamma^{*}\left(Y_{M^{*}}-Z\right)+Z\left(\gamma^{*}+\left(1-\gamma^{*}\right) P_{M}^{\varepsilon-1}\right)}{\gamma\left(Y_{M}+\frac{Z}{P_{M}}\right)} \\
& =\frac{\gamma^{*} Y_{M^{*}}+Z\left(1-\gamma^{*}\right) P_{M}^{\varepsilon-1}}{\gamma\left(Y_{M}+\frac{Z}{P_{M}}\right)}
\end{aligned}
$$

To provide some intuition for equation (14) it is useful to review some special cases. If there is no home bias, so that $\gamma+\gamma^{*}=1$, the equation becomes:

$$
P_{M}^{\varepsilon}=\frac{\gamma^{*} Y_{M^{*}}+Z\left(1-\gamma^{*}\right) P_{M}^{\varepsilon-1}}{\gamma\left(Y_{M}+\frac{Z}{P_{M}}\right)}
$$

The relative price of manufactures depends negatively on the overall supply of home versus foreign manufactures, the balance on nonmanufactures trade, and the elasticity of substitution between manufactures.

If it is further assumed that in initial equilibrium trade in both manufactures and nonmanufactures is balanced, and in initial equilibrium $\mathrm{P}_{\mathrm{M}}=1$, so that $\gamma=s /(1+s)$ and $\gamma^{*}=1 /(1+s)$, the right-hand side of the expression simplifies to:

$$
P_{M}^{\varepsilon}=\frac{Y_{M^{*}}+s Z P_{M}^{\varepsilon-1}}{s\left(Y_{M}+\frac{Z}{P_{M}}\right)}
$$

Only the relative supply of manufactures and nonmanufactures trade balance now matter. Finally, by making the two countries of equal size and eliminating commodities gives:

$$
P_{M}^{\varepsilon}=\frac{Y_{M^{*}}}{Y_{M}}
$$

Hence, the complexity of the generalized form of the equation comes from creating a flexible model in which a range of real-world situations can be examined.

Equation (14) is log-linearized to obtain a more easily estimable specification. As detailed in Appendix II, this results in the following specification: 


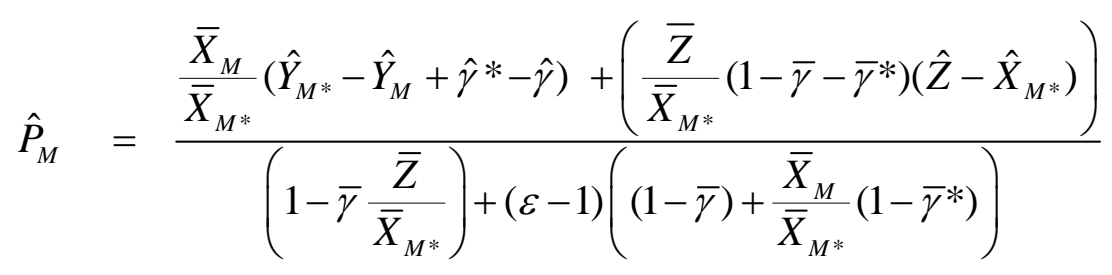

where bars above terms represent their equilibrium values, and hats are changes from equilibrium values, and $Z=P_{c} C-P_{c^{*}} C^{*}+T R$.

Equation (15) is the basic estimating equation of the paper. The numerator defines the underlying disturbances that can move the relative price of manufactures. The first term involves the relative supply and demand for home and foreign manufactured goods, as a rise in the quantity of home goods (for example) depresses their relative price on world markets. The second term shows that disturbances to the balance on commodity trade as well as transfers (comprising interest payments on international investment positions and uncompensated transfers) also matter, with the relative importance of these terms depending upon the relative importance of trade in manufactures and other flows in the overall trade accounts.

The denominator defines how much the relative price of manufactures varies in response to shocks. The first term is the expenditure-creating effect. A rise in the relative price of home manufactures leads to higher income in the home country, which sucks in more imports. The second term represents expenditure switching. As the elasticity of substitution rises, the relative price of manufactures has a larger impact on the trade balance, depending on home bias in domestic and foreign consumption. It also depends on the ratio of exports to imports of manufactures, as an exporter of manufactures has two margins along which the relative price operates (imports and exports of manufactures) while a commodity exporter has only one margin.

The influence of theory can be seen in the measurement of the explanatory variables and composition of the various coefficients. What matters are the relative output of manufactured goods; changes in nominal exports and imports of commodities, rather than the terms of trade; and trends in interest payments on international investments, rather than the path of net foreign assets. In addition, the coefficients depend upon numerous country-specific effects, such as the composition of trade and home bias of consumption.

\section{DATA AND SPECIFICATION}

We constructed the real exchange rate based on manufacturing output deflators, different from the conventional real exchange rate based on consumer prices, as our theory has the most distinct implication on the behavior of the manufacturing-based real exchange rate. We could construct this exchange rate for 10 advanced economies-Australia, Canada, Denmark, the euro area, Japan, Norway, New Zealand, Sweden, the United Kingdom, and the United States - for the period from 1980 to 2001 (see Appendix III for further details on data). 
For the right-hand side variables of equation (15), theory provides several specific guidelines for the choice and measurement of regressors. To start with the denominator of equation (15), which applies to all regressors, it depends on the elasticity of substitution among other things. Our initial attempt to estimate the elasticity of substitution was unsuccessful, which appears to reflect the conventional finding in the macro-empirics literature that the coefficient in question is close to 1 . If the coefficient is indeed equal to 1 , it has no effect on our specification, making it difficult for the econometric estimation of equation (15) to pick out a particular value. On the other hand, trade literature working with disaggregated models has often found a much higher value for this elasticity. We thus made a pragmatic choice of setting its value equal to 1.05 , close to the unit elasticity often used in the literature working with aggregate models.

The right-hand side variables of equation (15) are divided into three groups. The first term is captured by the log difference between real manufacturing output of home and foreign countries, and is named RYM in the rest of the paper. The commodity effects in the second term is captured by the log difference between the export and import prices of commodities, each augmented appropriately as indicated by theory. The commodity export price is multiplied by the ratio of commodity exports to noncommodity imports, and the commodity import price is multiplied by the ratio of commodity imports to noncommodity imports. The resulting variable is called TOT in the rest of the paper.

The major determinant of the transfer effects in the second term is the external financial position, for which several measures were used. We characterize separately flow receipts from gross foreign assets (ra*FA) and flow payments on gross foreign liabilities (rl*FL), dividing each by noncommodity imports. By using the gross inflows and outflows, we derive separate rates of return on external assets and liabilities.

Our first measure of external financial position is the net flow on foreign assets: rNFA = ra*FA - rl*FL, where the synthetic interest rate on net foreign assets, $r$, is a short-hand expression for the net inflow that is measured by allowing for separate rates of return on the asset and liability sides. The second measure of external financial position decomposes the first measure into the part driven by variation in the stock of net foreign assets ( $\bar{r} N F A$ ) and the remainder $((r-\bar{r}) N F A)$ driven by variation in the implied rates of return. Here again, synthetic interest rates on net foreign assets, $\bar{r}$ and $(r-\bar{r})$, are short-hand expressions for separate calculations that are based on separate average returns on the asset and liability sides. That is, $\bar{r} N F A=\overline{r a} * F A-\overline{r l} * F L$, and $(r-\bar{r}) N F A=r N F A-\bar{r} N F A$. The third measure relies only on the variation in the stock of net foreign assets, without regard to the variation in the rates of return $(\bar{r}$ NFA $)$. We do not introduce uncompensated international transfers because they are of negligible amount for countries in our sample. 
Incorporating these variables, we estimate a panel equation of the following type, in which country-specific fixed effects are allowed.

$$
\begin{aligned}
& R E E R_{i t}=\beta_{0 i}+\beta_{1} R Y M_{i t}+\beta_{2} T O T_{I T}+\beta_{3} r N F A_{i t}+u_{i t} \\
& R E E R_{i t}=\beta_{0 i}+\beta_{1} R Y M_{i t}+\beta_{2} T O T_{i t}+\beta_{3} \bar{r} N F A_{i t}+\beta_{4}(r-\bar{r}) N F A_{i t}+u_{i t} \\
& R E E R_{i t}=\beta_{0 i}+\beta_{1} R Y M_{i t}+\beta_{2} T O T_{i t}+\beta_{3} \overline{r N F A_{i t}}+u_{i t}
\end{aligned}
$$

Several issues arise in the econometric estimation, associated with the nonstationary nature of the data. On the basis of various unit root tests, all variables are viewed to be I(1) processes (Table 1). Reflecting the well-known difficulty of distinguishing I(1) and I(0) series in the finite sample, the battery of panel unit root tests does not always provide a unanimous answer. IPS test (column 1) often rejects the null hypothesis of unit root, while Breitung test (column 4) provides better support for the presence of unit roots in the data. However, the null hypothesis of $\mathrm{I}(0)$ is strongly rejected for all series, according to the test developed by Hadri (column 2).

For the correct statistical inference under nonstationary data, we used panel dynamic ordinary least squares estimation (panel DOLS), in line with Kao and Chiang (2000) and Mark and Sul (2000). The specific combination of dependent and independent variables changes with each specification, but all regressions are of the following format, where explanatory variable $z_{i t}$ refers to the vector of the corresponding dimensions.

$$
q_{i t}=\beta_{0 i}+\beta_{1} z_{i t}+\sum_{k=-m}^{m} \beta_{2} \Delta z_{i t+k}+\varepsilon_{i t}
$$

By including leads and lags of the differenced series, DOLS addresses an asymptotic bias contained in the OLS estimates. This econometric choice is based on Kao and Chiang (2000), who find that DOLS outperforms the alternative fully modified ordinary least squares (FMOLS) approach. For one, DOLS reduces bias better than FMOLS, while being computationally simpler. Second, the t-statistic from DOLS approximates the standard normal density much better than the statistics from OLS or FMOLS.

\section{Estimation RESUlts}

We test the basic theoretical prediction as summarized in equation (15), including the predictions that coefficients on different variables are identical in size and that the specifications are cointegrated. We then investigate how fast the exchange rate converges to the long-term value defined by the cointegrating equation, allowing the speed of convergence to vary nonlinearly with the distance from the long-term value. 


\section{A. Cointegrating Relationship}

Table 2 reports the long-run coefficients estimated for the manufacturing-based real exchange rate, corresponding to equation (19). In column (1), all external balance items are combined into one term (Z), while they are broken into TOT and NFA terms in the other three columns. The remaining three columns differ in their treatment of NFA terms. In column (2), NFA term measures the actual net flow income on foreign assets (rNFA); in column (3), the net flow income is decomposed into the part driven by changes in the stock of net foreign assets ( $\bar{r} N F A$ ) and the remainder driven by changes in the rate of return $((r-\bar{r}) N F A)$; and in column (4), the term that reflects variation in the rate of return is dropped.

Estimated coefficients are broadly consistent with the implications of theory. The coefficient on the RYM is strongly significant, and the estimates are around -0.7 , consistent with the predicted supply effect. When all external balance items are combined into one variable in column (1), the coefficient estimate is close to 1 , equal to the value predicted by theory. The hypothesis that these two coefficients are identical in size is not rejected by the Wald test at the 10 percent significance level (the test statistic is equal to 0.67 implying the p-value of 0.41). The cross-coefficient restrictions hold up in the specification for column (2), though less strongly. The hypothesis that the coefficients on RYM are identical in size to the coefficients on TOT and NFA terms is not rejected by the Wald test at the 10-percent significance level.

In columns (3) and (4) where NFA terms are broken down further, the cross-coefficient restrictions are strongly rejected at the 1 percent significance level. Similarly, the coefficient estimates are of the right sign but their magnitudes vary. The coefficient estimate on TOT is about 0.8 in columns (3) and (4), while it is smaller and not statistically significant in column (2). The coefficient estimate on NFA variables, in contrast, are about twice as large as the coefficient on the $\mathrm{Z}$ variable. The stronger statistical significance of NFA variables than TOT may be the combined effect of the persistence of underlying shocks and a finite sample. Our theoretical model focuses on the long-run relationship and does not allow for the differences engendered by the relative importance of shocks that do not have persistent effects. If shocks to TOT are more susceptible to short-term variations than shocks to NFA variables, our coefficient estimates based on this finite sample will capture the long-run relationship better for NFA variables than for TOT variables.

For each specification estimated in Table 2, we examine whether the real exchange rate is cointegrated with the explanatory variables on the basis of panel cointegration tests proposed by Pedroni $(2000,1999)$. Table 3 reports these test statistics under alternative measures for the NFA and TOT regressors across these various specifications. The residual-based tests assume a null of no cointegration. In the tables, the "panel” statistics impose common or pooled coefficients across individual panel units in deriving the corresponding test statistic, whereas the (less restrictive) group statistics represent the group mean of individual test statistics. Under the null, both sets of test statistics are shown to have a standard normal limiting distribution. Under the alternative, the panel $v$-statistic diverges to $+\infty$ while the 
other statistics diverge to - $\infty$, requiring the use of a right-tail test (i.e., positive critical values) in the first instance and left-tail tests (i.e., negative critical values) for all the other statistics. Strongest evidence in support of cointegration comes from ADF-type tests, while other tests often fail to reject the null of no cointegration.

\section{B. Convergence and Forecastability}

A central issue in the recent debates on the exchange rate has been the slow convergence to the long-run equilibrium. Accordingly, we explore how rapidly a deviation from the long-run cointegration relationship corrects itself in our model. In addition, we investigate if there is any nonlinearity in the speed of convergence toward the long-run relationship.

As the first step, we construct residuals from the cointegrating regression, calculated only on the basis of level-variables without including the leads and lags of first differences. We estimate the following second-stage error correction equation, allowing a nonlinear effect by including residual terms raised to the third power. The cubic term can capture the nonlinearity in the speed of convergence, while maintaining the sign of the deviation from the equilibrium.

$$
\Delta R E E R_{i t}=\gamma_{0 i}+\gamma_{1} R E S_{i t-1}+\gamma_{2}\left(R E S_{i t-1}\right)^{3}+\gamma_{3} \Delta R Y M_{i t-1}+\gamma_{4} \Delta T O T_{i t-1}+\gamma_{5} \Delta N F A_{i t-1}+u_{i t}
$$

Tables 4 and 5 correspond to the first-stage regressions of columns (2) and (3) of Table 2, respectively. When the deviation terms are included only in linear format, the half-life of deviations is two to three years, falling on the low-side of estimates obtained in the PPP literature, probably reflecting our specification that allows the long-run equilibrium exchange rates to vary over time, unlike the typical PPP literature.

When residual terms are included in both linear and cubic formats, we uncover statistically significant evidence of nonlinearity. The speed of convergence estimated by the linear term alone decreases, but the significant coefficient on cubic terms implies that the farther the exchange rate drifts away from the long-term trend, the faster it reverts toward the trend. It thus implies that unusually large deviations get corrected more rapidly, or that the speed of convergence rises with the size of the misalignment.

The fourth columns of Tables 4 and 5 contain a formal statistical confirmation of this finding, based on the following optimal nonlinear threshold model. When $I$ stands for an indicator function and $T$ stands for the optimal threshold,

$$
\Delta R E E R_{i t}=\gamma_{0 i}+\gamma_{1} R E S N_{i t-1}+\gamma_{2} R E S W_{i t-1}+\gamma_{3} \Delta R Y M_{i t-1}+\gamma_{4} \Delta T O T_{i t-1}+\gamma_{5} \Delta N F A_{i t-1}+u_{i t}
$$


where

$$
\begin{aligned}
& \operatorname{RESN}_{i t-1}=R E S_{i t-1} \cdot I_{\left(\left|R E S_{i t-1}\right|<T\right)} \\
& R E S W_{i t-1}=R E S_{i t-1} \cdot I_{\left(\left|R E S_{i t-1}\right|>T\right)}
\end{aligned}
$$

The optimal threshold is endogenously determined as a value that minimizes the sum of squared residuals.

The width of the threshold is estimated to be 15 percent on each side of the equilibrium in Table 4, and 9 percent each side in Table 5. In both tables, the convergence speed is faster outside the threshold than inside the threshold. Inside the threshold, the convergence speed is slower but statistically different from zero in Table 4, while statistically not different from zero in Table 5. To compare the convergence speed outside the threshold with the convergence speed of linear specification in column (1), the coefficient of nonlinear convergence is larger by $0.03-0.04$, implying that the half life outside the threshold is shorter by three to six months than the half life estimated by the linear specification. That is, outside the threshold, deviations from the long-run equilibrium decline more rapidly than most estimates of the PPP literature, while the convergence speed is slower or neatly equal to zero inside the threshold.

Finally, comparison of forecast errors is contained in Table 6. The mean squared error for random walk hypothesis is juxtaposed with the mean squared errors based on cointegrating regressions of columns (2) and (3) of Table 2. As in Meese and Rogoff (1983), the realized values of independent variables were used. Structural equations outbid random-walk model in four- or five-year horizon. This implies that the estimated cointegrating relationship offers a relevant benchmark for assessing the long-term trends in the real exchange rate.

\section{Conclusion}

This paper has examined the issue of equilibrium real exchange rates by developing and estimating a micro-founded theoretical model. In the two-country flexible-price model, the equilibrium real exchange rate depends on relative supply of manufactured goods, interest payments on debt, and commodity prices. The model is sufficiently flexible to take account of realistic differences across countries in terms of their relative size, the composition of their trade, the degree of home bias in consumption, and the elasticity of substitution between home and foreign manufactures while being simple enough to provide an analytical estimating equation involving novel ways of defining variables and introducing cross-country restrictions on coefficients.

Estimating the model using data for 11 industrial countries/currency areas using cointegration techniques, we find that all of the variables are correctly signed and statistically significant at conventional levels, and can be used to examine the path of the implied 
equilibrium exchange rate, the importance of the various underlying determinants in defining this path, and the speed of adjustment to equilibrium.

The regressions produce a number of important results. First, the implied paths of the real exchange rate appear consistent with heuristic discussions of exchange rate trends by policymaking institutions. Second, the regressions imply a relatively large level of uncertainty about the equilibrium value, consistent with the received wisdom in the profession. We also find strong evidence that the rate of convergence to equilibrium is affected by the size of the deviation from equilibrium. This helps explain why authors who assume a common convergence rate find such a surprisingly slow adjustment to equilibrium.

More generally, we hope to reinvigorate the analysis of equilibrium exchange rates, an issue that has fallen out of favor in recent years in the academic literature (but not in policy debates), by providing a theoretically sound and analytically tractable way of examining trends in real exchange rates across countries. Such a model allows researchers to move beyond the purchasing power parity model that has underlain much recent work on mediumterm exchange rate determination without recourse to ad hoc assumptions and empirical specifications. Examining the path of the equilibrium exchange rate over time can be extremely helpful in allowing economists to determine the degree to which movements in actual exchange rates have deviated from fundamentals and to offer some idea as to the likely rate of return to the underlying equilibrium. Such a system has immense practical value, as such medium-term trends in exchange rates are an essential tool in assessing current and future macroeconomic conditions in a country. Furthermore, given the generality of the underlying theoretical model, such an analysis is not limited to the industrial country exchange rates examined here, but can be used to examine exchange rates of developing nations. 


\section{REFERENCES}

Balassa, Bela, 1964, “The Purchasing Power Parity Doctrine: A Reappraisal,” Journal of Political Economy, Vol. 72 (December), pp. 584-96.

Cashin, Paul, Luis F. Céspedes, and Ratna Sahay, 2002, "Keynes, Cocoa, and Copper: In Search of Commodity Currencies,” IMF Working Paper 02/223 (Washington: International Monetary Fund).

Chen, Yu-Chin, and Kenneth Rogoff, 2003, “Commodity Currencies,” Journal of International Economics, Vol. 60 (May), pp. 133-60.

Choudhri, Ehsan, and Mohsin Khan, 2004, "Real Exchange Rates in Developing Countries: Are Balassa-Samuelson Effects Present?” IMF Working Paper 04/188 (Washington: International Monetary Fund).

Clark, Peter, and Ronald MacDonald, 1998, "Exchange Rates and Economic Fundamentals: A Methodological Comparison of BEERs and FEERs,” IMF Working Paper 98/67 (Washington: International Monetary Fund).

Faruqee, Hamid, 1995, “Long-Run Determinants of the Real Exchange Rate: A Stock-Flow Perspective,” Staff Papers International Monetary Fund, Vol. 42 (March).

Froot, Kenneth A., and Kenneth Rogoff, 1995, "Perspectives on PPP and Long-Run Real Exchange Rates,” Handbook of International Economics, Vol. 3, ed. by Gene M. Grossman and Kenneth Rogoff (Amsterdam: Elsevier Science Publishers), pp. 1647-88.

Gagnon, Joseph, 1996, “Net Foreign Assets and Equilibrium Exchange Rates: Panel Evidence,” Federal Reserve Board International Finance, Discussion Paper No. 574, (December) (Washington: U.S. Federal Reserve).

Im Kyung So, M. Hasnem Pesaran, and Yongcheol Shin, 2003, "Testing for Unit Roots in Heterogenous Panels,” Journal of Econometrics, No. 115, pp. 53-74.

Isard, Peter, and Hamid Faruqee, 1998, "Exchange Rate Assessment: Extensions of the Macroeconomic Balance Approach,” IMF Occasional Paper No. 167 (Washington: International Monetary Fund).

Kao, Chiwha, and Min-Hsien Chiang, 2000, "On the Estimation and Inference of A Cointegrated Regression in Panel Data,” Nonstationary Panels, Panel Cointegration and Dynamic Panels Vol. 15, pp. 179-222.

Lane, Philip R., and Gian Maria Milesi-Ferretti, 2001, “The External Wealth of Nations: Estimates of Foreign Assets and Liabilities for Industrial and Developing Countries,' Journal of International Economics 55, No. 2 (December) pp. 263-94. 
— 2004 , "The Transfer Problem Revisited: Net Foreign Assets and Real Exchange Rates," Review of Economics and Statistics, Vol. 86 (November).

Lee, Jaewoo, and Man-Keung Tang, 2003, "Does Productivity Growth Lead to Appreciation of the Real Exchange Rate?” IMF Working Paper 03/154 (Washington: International Monetary Fund), and Review of International Economics (forthcoming).

MacDonald, Roland and Jun Nagayasu, 2000, "The Long-Run Relation Between Real Exchange Rates and Real Interest Differentials: A Panel Study,” Staff Papers, International Monetary Fund, Vol. 47.

_ and Luca Antonio Ricci, 2002, “PPP and New Trade Theory,” IMF Working Paper 02/32 (Washington: International Monetary Fund).

Mark, Nelson, and Dooggyu Sul, 2001, "Nominal Exchange Rates and Monetary Fundamentals: Evidence from a Small Post-Bretton Woods Panel," Journal of International Economics, Vol. 53, pp. 29-52.

Meese, Richard, and Kenneth Rogoff, 1983, "Empirical Exchange Rate Models of the Seventies: Do They Fit Out of Sample?” Journal of International Economics, Vol. 14 (February), pp. 3-24.

Obstfeld, Maurice, and Kenneth Rogoff, 2000, “The Six Major Puzzles in International Macroeconomics: Is There a Common Cause?” NBER Macroeconomics Annual 2000, ed. by Ben Bernanke and Kenneth Rogoff (Cambridge, Massachusetts: MIT Press), pp. 339-90.

Pedroni, Peter, 1999, "Critical Values for Cointegration Tests in Heterogeneous Panels with Multiple Regressors," Oxford Bulletin of Economics and Statistics, Vol. 61: 4, pp. 653-70.

_ , 2000, "Fully-Modified OLS for Heterogeneous Cointegrated Panels," Advances in Econometrics, Vol. 15, pp. 93-130.

Rogoff, Kenneth, 1996, “The Purchasing Power Parity Puzzle,” Journal of Economic Literature, Vol. 34, (June), pp. 647-68.

Samuelson, Paul, 1964, “Theoretical Notes on Trade Problems," Review of Economics and Statistics, Vol. 46 (March), pp. 145-54.

Stock, James and Mark Watson, 1993, "A Simple Estimator of Cointegrating Vectors in Higher Order Integrated Systems,” Econometrica, Vol. 61, pp. 783-820.

Williamson, John, 1994, Estimating Equilibrium Exchange Rates (Washington: Institute of International Economics). 


\section{Derivation of Relative Price of Commodities}

The intensity of land use depends upon the relative price of land to wages:

$$
\begin{aligned}
& A=\bar{A}\left(\frac{P_{C}}{W}\right)^{\lambda} \\
& A^{*}=\bar{A} *\left(\frac{P_{C}}{W}\right)^{\lambda^{*}}
\end{aligned}
$$

and hence the output of commodities are:

$$
\begin{aligned}
& Y_{C}=T_{C} \bar{A}\left(\frac{P_{C}}{W}\right)^{\lambda} \\
& Y_{C^{*}}=T_{C^{*}} \overline{A^{*}}\left(\frac{P_{C^{*}}}{W^{*}}\right)^{\lambda^{*}}
\end{aligned}
$$

where $\mathrm{Y}_{\mathrm{C}}$ and $\mathrm{Y}_{\mathrm{C}^{*}}$ are the output of the two commodities, $\bar{A}$ and $\bar{A}^{*}$ are the amounts of land used in initial equilibrium, and $\lambda$ and $\lambda^{*}$ are positive constants that are less than one.

As the demand for commodities is proportional to labor inputs times the Leontief coefficients:

$$
\begin{aligned}
& Y_{C}=\varphi_{c}(1+s) \\
& C_{C}=\varphi_{c} \text { and } X_{C}=\varphi_{c} s \\
& Y_{C^{*}}=\varphi_{c^{*}}(1+s) \\
& C_{C^{*}}=\varphi_{c^{*}} s \text { and } X_{C^{*}}=\varphi_{c^{*}} s
\end{aligned}
$$

where $\mathrm{Y}_{\mathrm{C}}, \mathrm{C}_{\mathrm{C}}$, and $\mathrm{X}_{\mathrm{C}}$ represent output, home consumption, and exports of the home commodity to the rest of the world, with starred variables represent the same concepts for the foreign country.

Accordingly, the relative price of each commodity is:

$$
\begin{aligned}
& P_{c}=P_{M} T_{M}\left(\frac{\varphi_{c}(1+s)}{T_{c} \bar{A}}\right)^{1 / \lambda} \\
& P_{c^{*}}=T_{M^{*}}\left(\frac{\varphi_{c^{*}}(1+s)}{T_{c^{*}} \overline{A^{*}}}\right)^{1 / \lambda^{*}}
\end{aligned}
$$




\section{Derivation of Log-linearized Exchange Rate Equation}

Log-linearizing equation (14):

$$
\frac{P_{M}\left(\gamma^{*}+\left(1-\gamma^{*}\right) P_{M}^{\varepsilon-1}\right)}{\gamma+(1-\gamma) P_{M}^{-(\varepsilon-1)}}=\frac{\gamma^{*}\left(Y_{M^{*}}-Z\right)+Z\left(\gamma^{*}+\left(1-\gamma^{*}\right) P_{M}^{\varepsilon-1}\right)}{\gamma\left(Y_{M}+\frac{Z}{P_{M}}\right)}
$$

involves deriving expressions for the numerator and denominator. Assuming that $\mathrm{P}_{\mathrm{M}}=1$ in equilibrium, for the left-hand side, the following approximation is involved:

$$
\Delta\left(\gamma^{*}+\left(1-\gamma^{*}\right) P_{M}^{\varepsilon-1}\right) \approx\left(1-\gamma^{*}\right)(\varepsilon-1) \hat{P}_{M}
$$

Turning to the numerator of the right hand side, and noting that $\gamma^{*}\left(Y_{M^{*}}-Z\right)=P_{M} X_{M}$ and

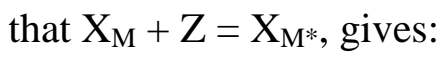

$$
\begin{aligned}
\Delta\left(\gamma^{*}\left(Y_{M^{*}}-Z\right)+Z\left(\gamma^{*}+\left(1-\gamma^{*}\right) P_{M}^{\varepsilon-1}\right)\right) \\
\quad \approx \frac{\bar{X}_{M}}{\bar{X}_{M^{*}}}\left(\hat{Y}_{M^{*}}+\hat{\gamma}^{*}-\frac{\bar{Z}}{\bar{Y}_{M^{*}}} \hat{Z}\right)+\frac{\bar{Z}}{\bar{X}_{M^{*}}}\left(\hat{Z}+\left(1-\gamma^{*}\right)(\varepsilon-1) \hat{P}_{M}\right) \\
\quad \approx \frac{\bar{X}_{M}}{\bar{X}_{M^{*}}}\left(\hat{Y}_{M^{*}}+\hat{\gamma}^{*}\right)+\frac{\bar{Z}}{\bar{X}_{M^{*}}}\left(1-\gamma^{*}\right)\left(\hat{Z}+(\varepsilon-1) \hat{P}_{M}\right)
\end{aligned}
$$

For the denominator of the right-hand side we have:

$$
\begin{aligned}
\Delta\left(\gamma\left(Y_{M}+\frac{Z}{P_{M}}\right)\right) & \approx \Delta\left(X_{M^{*}}^{\frac{\bar{Z}}{\bar{M}^{*}}}\left(\gamma\left(Y_{M}+\frac{Z}{P_{M}}\right)\right)^{\frac{\bar{X}_{M}}{\bar{X}_{M^{*}}}}\right) \\
& \approx \frac{\bar{Z}}{\bar{X}_{M^{*}}} \hat{X}_{M^{*}}+\frac{\bar{X}_{M}}{\bar{X}_{M^{*}}} \bar{\gamma}\left(\hat{Y}_{M}+\hat{\gamma}+\frac{\bar{Z}}{\bar{X}_{M^{*}}} \gamma\left(\hat{Z}-\hat{P}_{M}\right)\right)
\end{aligned}
$$

Combining and manipulating gives equation (14) in the text. 


\section{Data Sources}

Most manufacturing data-deflators and output-were obtained from the OECD's STAN database. When not available from STAN, manufacturing data were obtained from the OECD's ANIA data for industry, a sector that includes energy production. Trade weights used in constructing effective exchange rates came from the UN's UNCTAD database. The output, prices, and trade composition of commodities came from the UN's UNCTAD database, too. The data on income flows come from IFS and the data on external assets and liabilities come from Lane and Milessi-Ferretti (2001). We calculate the implied rates of return on assets and liabilities separately, by combining the data on income flows and on asset and liability positions. 
Table 1 : Unit Root Tests

\begin{tabular}{lcccc}
\hline Variable & $(1)$ & $(2)$ & $(3)$ & $(4)$ \\
\hline & & & & \\
REER & $-1.41^{\mathrm{a}}$ & $8.06^{\mathrm{b}}$ & 2.08 & -0.83 \\
REERMAN & $-1.23^{\mathrm{a}}$ & $8.76^{\mathrm{b}}$ & $6.06^{\mathrm{b}}$ & 0.26 \\
TNT & -0.96 & $11.31^{\mathrm{b}}$ & $8.99^{\mathrm{b}}$ & 1.01 \\
RPMAN & 0.58 & $9.58^{\mathrm{b}}$ & $10.44^{\mathrm{b}}$ & $1.49^{\mathrm{a}}$ \\
RYM & -0.71 & $10.21^{\mathrm{b}}$ & $9.90^{\mathrm{b}}$ & 0.85 \\
Z & $-1.63^{\mathrm{a}}$ & $6.67^{\mathrm{b}}$ & $-6.36^{\mathrm{b}}$ & $-1.34^{\mathrm{a}}$ \\
TOT & $-3.84^{\mathrm{b}}$ & $3.21^{\mathrm{b}}$ & $-8.34^{\mathrm{b}}$ & $-1.27^{\mathrm{a}}$ \\
$r N F A$ & -0.93 & $7.95^{\mathrm{b}}$ & $-4.32^{\mathrm{b}}$ & $-2.25^{\mathrm{b}}$ \\
$\bar{r} N F A$ & $1.70^{\mathrm{a}}$ & $15.36^{\mathrm{b}}$ & -0.25 & 0.56 \\
$(r-\bar{r}) N F A$ & -0.12 & $7.85^{\mathrm{b}}$ & -8.38 & $-3.42^{\mathrm{b}}$ \\
rA & -0.91 & $9.61^{\mathrm{b}}$ & $8.67^{\mathrm{b}}$ & 0.05 \\
rL & $-2.48^{\mathrm{b}}$ & $6.07^{\mathrm{b}}$ & $7.55^{\mathrm{b}}$ & -0.08 \\
& & & & \\
\hline
\end{tabular}

I. Im, Pesaran and Shin (1995).

II. Hadri (2000).

III. Levin and Lin (1992).

IV. Breitung (2000).

a denotes significance at 10 percent level.

${ }^{\mathrm{b}}$ denotes significance at 5 percent level. 
Table 2. Panel Estimates of Long-run Coefficients (Dependent Variable: Manufacturing-based REER; $N=10, T=22$ )

\begin{tabular}{|c|c|c|c|c|}
\hline Variable & (1) & (2) & (3) & (4) \\
\hline$R Y M$ & $\begin{array}{c}-0.71 \\
(-2.74)\end{array}$ & $\begin{array}{c}-0.64 \\
(-2.58)\end{array}$ & $\begin{array}{c}-0.68 \\
(-3.20)\end{array}$ & $\begin{array}{c}-0.69 \\
(-3.11)\end{array}$ \\
\hline$Z$ & $\begin{array}{c}1.01 \\
(3.32)\end{array}$ & $\ldots$ & $\ldots$ & $\ldots$ \\
\hline TOT & $\ldots$ & $\begin{array}{c}0.58 \\
(1.49)\end{array}$ & $\begin{array}{c}0.78 \\
(2.33)\end{array}$ & $\begin{array}{c}0.85 \\
(2.42)\end{array}$ \\
\hline$r N F A$ & $\ldots$ & $\begin{array}{c}1.75 \\
(3.59)\end{array}$ & $\ldots$ & $\ldots$ \\
\hline $\bar{r} N F A$ & $\cdots$ & $\cdots$ & $\begin{array}{c}2.59 \\
(5.53)\end{array}$ & $\begin{array}{c}2.29 \\
(5.30)\end{array}$ \\
\hline$(r-\bar{r}) N F A$ & $\cdots$ & $\cdots$ & $\begin{array}{c}0.63 \\
(1.17)\end{array}$ & $\ldots$ \\
\hline $\begin{array}{l}\text { Wald Test } \\
\text { (p-value) }\end{array}$ & $\begin{array}{c}0.67 \\
(0.41)\end{array}$ & $\begin{array}{c}4.13 \\
(0.13)\end{array}$ & $\begin{array}{c}18.45 \\
(0.0004)\end{array}$ & $\begin{array}{c}11.13 \\
(0.0038)\end{array}$ \\
\hline
\end{tabular}

Panel estimates based on Stock-Watson Dynamic OLS (DOLS) estimator; panel regression also includes 1 lead and s lag and contemporaneous changes in the regressors; corrected $t$-statistics appear in parentheses. 
Table 3. Panel Cointegration Statistics

$(N=10, T=22)$

\begin{tabular}{llcrc}
\hline & $(1)$ & $(2)$ & $(3)$ & $(4)$ \\
Test Statistic & & & \\
& & & \\
Panel $v$ & 0.87 & 0.23 & -0.34 & 0.52 \\
Panel $\rho$ & -0.58 & 0.30 & 1.39 & 0.46 \\
Panel Phillips-Perron & $-1.86^{*}$ & -1.48 & -0.33 & -1.05 \\
Panel ADF & $-2.91^{* *}$ & $-2.10^{* *}$ & -0.81 & $-1.90^{*}$ \\
Group $\rho$ & 0.40 & 1.48 & 2.52 & 1.53 \\
Group Phillips-Perron & $-1.69^{*}$ & -1.02 & 0.16 & -0.73 \\
Group ADF & $-3.27^{* *}$ & $-2.00^{* *}$ & -0.75 & $-2.23^{* *}$ \\
$\quad$ Number of & & & $k=4$ & $k=3$ \\
Regressors & $k=2$ & $k=3$ & & \\
\hline
\end{tabular}

Panel cointegration tests based on Pedroni $(1997,1999)$. A *(**) indicates significance at the 10 (5) percent level. Specifications for each column are as follows. (1) RYMAN and $Z$ as regressors; (2) RYMAN , ZNFA and ZTOT as regressors; (3) RYMAN , ZNFA and ZTOT as regressors; and (4) RYMAN , ZTOT , and ZRBARNFA as regressors 
Table 4. Panel Estimates of Error-Correction Model (Dependent Variable: Manufacturing-based REER; $N=10, T=22$ )

\begin{tabular}{|c|c|c|c|c|}
\hline Variable & (1) & (2) & (3) & (4) \\
\hline$\triangle R E S$ & $\begin{array}{c}-0.22 \\
(-4.48)\end{array}$ & $\ldots$ & $\begin{array}{c}-0.12 \\
(-1.55)\end{array}$ & $\cdots$ \\
\hline$\Delta(R E S)^{3}$ & ... & $\begin{array}{c}-4.37 \\
(-4.60)\end{array}$ & $\begin{array}{c}-2.68 \\
(-1.84)\end{array}$ & $\ldots$ \\
\hline$\triangle R E S N$ & $\ldots$ & $\ldots$ & ... & $\begin{array}{c}-0.17 \\
(-2.46)\end{array}$ \\
\hline$\triangle R E S W$ & $\ldots$ & $\ldots$ & $\ldots$ & $\begin{array}{l}-0.26 \\
(-4.08)\end{array}$ \\
\hline$\triangle R E E R$ & $\begin{array}{c}0.28 \\
(3.87)\end{array}$ & $\begin{array}{c}0.26 \\
(3.61)\end{array}$ & $\begin{array}{c}0.28 \\
(3.86)\end{array}$ & $\begin{array}{c}0.29 \\
(3.92)\end{array}$ \\
\hline$\Delta R Y M$ & $\begin{array}{c}0.15 \\
(0.96)\end{array}$ & $\begin{array}{c}0.23 \\
(1.51)\end{array}$ & $\begin{array}{c}0.18 \\
(1.17)\end{array}$ & $\begin{array}{c}0.15 \\
(0.99)\end{array}$ \\
\hline$\triangle T O T$ & $\begin{array}{c}0.20 \\
(1.63)\end{array}$ & $\begin{array}{c}0.23 \\
(1.91)\end{array}$ & $\begin{array}{c}0.20 \\
(1.67)\end{array}$ & $\begin{array}{c}0.20 \\
(1.58)\end{array}$ \\
\hline$\triangle N F A$ & $\begin{array}{c}-0.05 \\
(-0.25)\end{array}$ & $\begin{array}{c}0.01 \\
(0.03)\end{array}$ & $\begin{array}{c}-0.05 \\
(-0.26)\end{array}$ & $\begin{array}{c}-0.06 \\
(-0.31)\end{array}$ \\
\hline
\end{tabular}

Panel estimation of second-stage error correction model based on cointegrating relation of column (2); $t$-statistics appear in parentheses. The optimal threshold for RESW is 0.151. 
Table 5. More Panel Estimates of Error-Correction Model (Dependent Variable: Manufacturing-based REER; $N=10, T=22$ )

\begin{tabular}{|c|c|c|c|c|}
\hline Variable & (1) & (2) & (3) & (4) \\
\hline$\triangle R E S$ & $\begin{array}{c}-0.29 \\
(-5.33)\end{array}$ & $\ldots$ & $\begin{array}{l}-0.20 \\
(-2.77)\end{array}$ & $\cdots$ \\
\hline$\Delta(R E S)^{3}$ & $\ldots$ & $\begin{array}{c}-3.56 \\
(-4.88)\end{array}$ & $\begin{array}{c}-1.80 \\
(-1.88)\end{array}$ & $\ldots$ \\
\hline$\triangle R E S N$ & $\ldots$ & $\ldots$ & $\ldots$ & $\begin{array}{c}-0.16 \\
(-1.35)\end{array}$ \\
\hline$\triangle R E S W$ & $\ldots$ & $\ldots$ & $\ldots$ & $\begin{array}{c}-0.32 \\
(-5.42)\end{array}$ \\
\hline$\triangle R E E R$ & $\begin{array}{c}0.29 \\
(4.07)\end{array}$ & $\begin{array}{c}0.25 \\
(3.56)\end{array}$ & $\begin{array}{c}0.30 \\
(4.16)\end{array}$ & $\begin{array}{c}0.30 \\
(1.57)\end{array}$ \\
\hline$\Delta R Y M$ & $\begin{array}{c}0.20 \\
(1.37)\end{array}$ & $\begin{array}{c}0.45 \\
(2.92)\end{array}$ & $\begin{array}{c}0.31 \\
(1.97)\end{array}$ & $\begin{array}{c}0.24 \\
(1.57)\end{array}$ \\
\hline$\triangle T O T$ & $\begin{array}{c}0.18 \\
(1.44)\end{array}$ & $\begin{array}{c}0.19 \\
(1.55)\end{array}$ & $\begin{array}{c}0.15 \\
(1.23)\end{array}$ & $\begin{array}{c}0.17 \\
(1.36)\end{array}$ \\
\hline$\overline{\Delta r} N F A$ & $\begin{array}{c}-0.82 \\
(-2.24)\end{array}$ & $\begin{array}{c}-0.63 \\
(-1.72)\end{array}$ & $\begin{array}{c}-0.81 \\
(-2.24)\end{array}$ & $\begin{array}{c}-0.80 \\
(-2.17)\end{array}$ \\
\hline$\Delta(r-\bar{r}) N F A$ & $\begin{array}{c}0.30 \\
(1.62)\end{array}$ & $\begin{array}{c}0.35 \\
(1.84)\end{array}$ & $\begin{array}{c}0.33 \\
(1.75)\end{array}$ & $\begin{array}{c}0.31 \\
(1.69)\end{array}$ \\
\hline
\end{tabular}

Panel estimation of second-stage error correction model based on cointegrating relation of column (3); $t$-statistics appear in parentheses. The optimal threshold for RESW is 0.089 . 
Table 6. Forecast Errors

(Mean Squared Error)

\begin{tabular}{lccc}
\hline Forecast Horizon & Random Walk & Cointegration (2) & Cointegration (3) \\
\hline 1 Year & 0.004 & 0.017 & 0.015 \\
2 Years & 0.010 & 0.017 & 0.017 \\
3 Years & 0.014 & 0.016 & 0.018 \\
4 Years & 0.018 & 0.017 & 0.020 \\
5 Years & 0.023 & 0.018 & 0.018 \\
\hline
\end{tabular}

Panel estimation of second-stage error correction model; $t$-statistics appear in parentheses. Structural forecast is based on cointegrating relationship of columns (2) and (3) in Table 2. 